\title{
Digitalization of Criminal Proceedings in the Context of the Coronavirus Pandemic (Covid-19) in Uzbekistan
}

\author{
Dilbar Suyunova $^{1}$, Behruz Shamsutdinov ${ }^{2}$ \\ ${ }^{1}$ Acting Professor, ${ }^{2}$ Lecturer, Department of Criminal Procedural Law, Tashkent State University of Law, \\ 35 Sayilgoh, Tashkent, 100047, Uzbekistan
}

\begin{abstract}
The widespread introduction of modern technologies in all spheres of life, including in the activities of the judiciary, has made it possible to make justice accessible to citizens. This became especially obvious due to the negative impact of the COVID-19 pandemic on the administration of justice, including the legal regulation of public relations in the field of criminal justice. The consideration of criminal cases in the mode of videoconferencing in the context of the pandemic contributed to the acceleration of the use of digital technologies in judicial activities. The goal of the research is to consider some issues related to the use of digital technologies in criminal proceedings, especially in the context of the spread of coronavirus infection and the introduction of quarantine measures.
\end{abstract}

Keywords: Criminal justice, digitalization, videoconferencing, electronic document management, rights and freedoms of citizens, coronavirus pandemic, COVID-19.

\section{Introduction}

It should be recognized that the introduction of information and communication technologies into judicial activity was not an innovation when it became known about the COVID-19 pandemic as a global challenge to the entire world community. By this time, the courts of many states, including Uzbekistan, used in criminal proceedings the experience of conducting court proceedings in the mode of videoconferencing (VKS), automatic distribution of cases, fixing the course and results of investigative actions with audio and video recordings, publishing court decisions on the Internet, sending executive documents for compulsory execution in electronic format, etc.

The use of digital technologies by courts in Uzbekistan dates back to the adoption of the Resolution of the Cabinet of Ministers of the Republic of Uzbekistan "On measures to introduce modern information and communication technologies into the activities of courts" dated December 10, 2012, which was the basis for the provision of interactive services and the introduction of electronic document management into the judicial system. Since 2013, Uzbekistan has developed and launched the National Information System of Electronic Judicial Proceedings "E-SUD".
By the Law of the Republic of Uzbekistan dated May 23, 2019, amendments were made to the criminal procedure legislation regarding the use of videoconferencing in criminal proceedings. This computer technology has made it possible to conduct trials at a considerable distance when the court and the convicted person are far from each other. Positive aspects can be noted when considering a criminal case in the videoconferencing regime: the possibility for witnesses, victims who are outside the territory where the trial is taking place, to save their money, to participate in court and give evidence at the place of residence, the likelihood of interrogating additional witnesses in court to establish truth in the case, reduction of the time for consideration of cases.

With the onset of the COVID-19 pandemic, the relevance of remote court hearings has increased, the highest judicial body of Uzbekistan explained to the courts about the need to take measures to timely consider criminal cases using videoconferencing ${ }^{1}$.

It should be noted that to protect the rights and freedoms of citizens, ensure openness and transparency of the courts, the leadership of Uzbekistan is taking all necessary measures, including those aimed at introducing modern information and communication 
technologies into the judicial system. On September 3, 2020, the President of Uzbekistan signed the Decree "On Measures to Digitalize the Activities of the Judiciary", which defines the tasks of digitalizing the activities of the judicial authorities, namely: ensuring the openness and transparency of the activities of the judicial community by introducing special information programs; expanding the possibility of remote participation in court sessions, including through mobile devices and other forms of electronic interaction, as well as creating conditions for the parties to receive court decisions online; recording of court sessions in all courts using audio recording based on the petition of the parties in the case and with the consent of the presiding judge, as well as the formation of court records using the system of automatic generation of court documents, the development of a mobile application that provides an opportunity to participate in court sessions in the mode of videoconferencing and much more ${ }^{2}$.

\section{Method}

The article uses general scientific research method, the method of system analysis of the theoretical foundations of the task, the practice of using digital technologies in Uzbekistan and some foreign countries.

Findings: The digitalization of the activities of the courts will undoubtedly ensure openness and transparency in the consideration of criminal cases, increase the level of citizens' access to justice, and facilitate effective interaction of courts with the bodies of inquiry, preliminary investigation to promptly consider criminal cases. In Uzbekistan, the country's leadership and its government have taken appropriate decisions regarding the digitalization of the activities of the judiciary. In the country's law enforcement practice, the procedure for considering criminal cases via videoconferencing is successfully applied.

\section{Discussion and Results}

In different countries of the world, procedures related to the introduction of remote justice have both similarities and differences. In many countries, before the outbreak of the COVID-19 pandemic, laws and regulations on the organization of videoconferencing in court sessions had already been passed. However, it was the coronavirus pandemic and the quarantine measures taken by the states that became a kind of the impetus for the mass use of communication technologies by courts.
Professor Richard Susskind, a member of the Computer and Law Society of Britain, has dedicated an entire book on the active implementation of modern technology in the judicial system ${ }^{3}$. Under his leadership, the Internet project "Remote Courts Worldwide" was implemented, which allowed all the judges of the world to share their experience for the development of remote justice 4 .

Videoconferencing is being conducted by UK courts via Skype for Business at HMCTS. To join these video conferences, a free Skype meeting application has been developed. Each participant in the criminal case receives instructions and a link to go to the hearing as a "guest". The issue of communication between a lawyer and his client in the UK was resolved by introducing an independent system, outside of interaction in the criminal process, through which a lawyer and his client can communicate for an unlimited time ${ }^{5}$.

Besides, the UK Courts and Tribunals Service is expanding its cloud-based video platform to enable remote hearings for any courtroom that has the technology and the right equipment. Participants in the process can access such a meeting through any laptop or video device. There are video points in courts, prisons and police stations. The instruction dictates that on the day of the hearing of the case, all participants must be in a closed, quiet place where they cannot be overheard. They should be prepared to take on a challenge during the meeting An employee of the Courts and Tribunals Service helps to connect to the system. He also records the hearings and ensures its storage.

Since 1995, the Court Call company has been operating in the United States, providing the remote presence of the parties at court hearings. During a pandemic, the company's employees not only connect the parties and the courts by phone, but also organize court sessions in the videoconferencing mode, as well as check the appearance and identity of persons participating in court sessions, and monitor the quality of communication to help the judges ${ }^{6}$.

Professor Michael Legg of the University of South Wales in Sydney, Australia, in his article "COVID-19 Pandemic, Courts and Online Hearings: Maintaining Open Justice, Procedural Fairness and Impartiality"7, pointed out that "even in a pandemic, the courts must function under their institutional role and its main characteristics". This article uses the unique 
circumstances of the pandemic to consider how courts can use technology while still upholding the core or substantive demands of the court and identifies the three core characteristics of courts - open justice, procedural fairness and impartiality".

In July 2020, Judge Lee Seyu Kin was one of the first to conduct a virtual trial in Singapore. Subsequently, the state took appropriate measures to transfer almost all courts online, which gave positive results. We learned about how Singapore's judicial system quickly switched to remote hearings during the COVID-19 pandemic in an article by Aaron Jung, Secretary of the Supreme Court of Singapore ${ }^{8}$. In particular, the author indicated that the adopted "Law on COVID-19" provided for the conduct of trials and proceedings in the Sharia court using remote communication technologies. However, the accused or witness may testify via live video link or live TV broadcast approved by the Chief Justice. Appearances and other testimonies given through remote communication are accepted in the same way as they were given in the courtroom.

In Spain, on 28 April 2020, Royal Decree-Law $16 / 2020$ was issued on procedural and organizational measures to combat COVID-19 in the area of administration of justice ${ }^{9}$. The provisions of the Law provided for the possibility of carrying out procedural actions (including court sessions) in telematic presence, provided that the courts, tribunals and prosecutors have the necessary technical means at their disposal.

The Bulgarian parliament has allowed courts to use videoconferencing in administrative, civil and criminal proceedings. Persons involved in the case may request participation in the court hearing through the HQS if they cannot attend in person. In this case, the trial must be held in a regional court equipped for videoconferencing.

In Germany, in addition to conducting court sessions in the videoconferencing regime, an electronic dossier is created with digitized materials of the criminal case, and to reduce the time for acquaintance with the materials of the criminal case, the defender receives its electronic materials through his special e-mail box ${ }^{10}$.

An analysis of the practice of courts on the use of information technology in the administration of justice has shown that during the period of restrictive measures associated with the coronavirus pandemic, most countries of the world have transferred legal proceedings to a remote format to prevent the threat of the spread of coronavirus infection.

At the same time, the increase in the volume of criminal cases, the consideration of which is carried out in the videoconferencing regime, the conduct of electronic document management has revealed some features of information technology. The analysis of the remote court session showed the following:

- In areas remote from the centre, there is still a problem with connecting to a single Internet network;

- Not all citizens acting as victims, witnesses can use new technologies, the trial and interview of its participants in most cases takes place in court buildings, which can put pressure on victims and witnesses when they give evidence;

- Network insecurity, i.e. conducting a public court session via the Internet can give wide publicity to the participation of a citizen in court and cause a violation of his honour and dignity;

- The participation of the accused in custody in the court session in the videoconferencing regime and giving testimony to them raises some doubts about their veracity since the interview procedure is carried out with the participation of employees of the remand prison;

- It is noted that the conduct of the court session in the videoconferencing regime limits the rights of the defender and the accused to talk with each other, correct their testimony and formulate questions;

- Lack of legislative regulation of the court session in the format of the videoconferencing.

\section{Conclusions}

The introduction of digital technologies in the activities of courts, the holding of court sessions in the videoconferencing regime, especially during the COVID-19 pandemic, helped to solve the primary tasks of the state in the administration of justice. But still, given the specifics of criminal proceedings, the following factors should be taken into account, requiring an early decision.

1. When working with electronic documents, legislative protection against unauthorized access and prevention of changes in their content to documents is required. Digitalization must meet the requirements of criminal proceedings, its features, 
including those related to the confidentiality of the testimony of victims, witnesses and other participants in the process.

2. During the height of the COVID-19 pandemic, the likelihood of its second wave, there is a need to develop a unified digital platform for courts with an increased level of channel protection, through which the information of persons involved in the case is transmitted, as well as an independent server for storing information on each specific case ... It is pertinent to note the specifics of cases in which offline court hearings would be held in closed court sessions (crimes against sexual freedom, in cases involving state secrets, etc.) since this issue should be regulated separately in the law.

3. Conducting court sessions in the videoconferencing regime should in no way violate the rights of participants in criminal proceedings. The accused must be allowed to communicate with his defence lawyer in unlimited time, victims and witnesses must give their testimony in court freely, without any pressure from the organizers of the videoconferencing process. At the same time, ensuring the safety of all participants in a trial is a fundamental element of a fair trial.

4. All participants in the process should be guaranteed the right to defend both the accused and the victims and witnesses. As a rule, the defender needs to provide a separate room with an established Internet network or Skype, to communicate freely with his client in an unlimited period. In this context, the accused should also be ensured his right to an objective, a free narration of the events of the crime, since the accused in custody participates in the court session in the videoconferencing regime in the presence of the staff of the institution for the execution of punishment and is under their supervision.

5. Of course, we cannot completely replace real litigation with digital technologies. However, today's events related to the coronavirus pandemic have forced the judiciary to use the power of videoconferencing in judicial activities, and thus exercise their functions of administering justice.

Therefore, our task is to use new technologies only with the condition of guaranteeing the rights of citizens participating in criminal proceedings. Besides, it should be borne in mind that when assessing the evidence collected in the case, the court must check their reliability, taking into account the quality of the image, sound and other factors that may subsequently be important for deciding whether a person is guilty or innocent.

The danger of the spread of coronavirus infection obliged judges to promptly consider criminal cases using digital technologies. It is necessary to thoroughly analyze the current practice of the courts in the consideration of criminal cases in the mode of videoconferencing and develop the necessary legislative mechanisms to regulate the use of digital technologies. This process should in no way violate the rights and freedoms of citizens guaranteed by the Constitution.

Conflict of Interest: None to declare

\section{Source of Funding: Self}

Ethical Approval: No ethical approval is needed.

\section{References}

1. www.supcourt.uz. Resolution of the Plenum of the Supreme Court of the Republic of Uzbekistan "On some issues of the application of legislation by the courts in connection with the introduction in the territory of the Republic of Uzbekistan of measures to prevent the spread of coronavirus infection COVID-19."

2. Resolution of the President of the Republic of Uzbekistan from September 3, 2020 of No. PP4818 "On measures for digitization of activity of judicial authorities"//https://lex.uz/docs/4979899

3. Professor Richard Susskind OBE, Visiting Professor and Advisory Board Chair//https://www. oii.ox.ac.uk/people/richard-susskind/

4. Remote Courts Worldwide: News//https:// remotecourts.org/news.htm

5. Найти баланс: каким будет онлайн-правосудие в России//https://pravo.ru/story/221644/

6. Remote Appearance Platform//https://courtcall. com/

7. Legg, Michael, COVID-19 Pandemic, Courts and Online Hearings: Maintaining Open Justice, Procedural Fairness and Impartiality (2021). Upcoming (2021) Review of Federal Law, UNSW Law Research No. 20-46, available on SSRN: https://ssrn.com/abstract=3681165 
8. Academy Publishing's Journals Online//https:// journalsonline.academypublishing.org.sg/Portals/

9. «BOE» núm. 119, de 29 de abril de 2020, páginas 30623 a 30645 (23 págs.)//https://www.boe.es/eli/ es/rdl/2020/04/28/16

10. Anufrieva E.A, Omelchenko T.V. The Main Directions of Digitalization of the Criminal Process in Russia//Problems of Obtaining and Using Evidence and Forensic Information: materials of the scientific and practical conference September 26-27, 2019, Miskhor (Big Yalta)/resp. ed. M.A. Mikhailov, T.V. Omelchenko; Crimean Federal University named after V.I. Vernadsky. Simferopol: IT «ARIAL», 2019. P. 4-5. 